Correction: Treatment effects of systematic two-stent and provisional stenting techniques in patients with complex coronary bifurcation lesions: rationale and design of a prospective, randomised and multicentre DEFINITION

\title{
II trial
}

Zhang J, Gao X, Han Y, et al. Treatment effects of systematic two-stent and provisional stenting techniques in patients with complex coronary bifurcation lesions: rationale and design of a prospective, randomised and multicentre DEFINITION II trial. BMJ Open 2018;8:e20019. doi: 10.1136/bmjopen-2017-020019.

The sample size estimation in Statistical Analysis Part should be:

From previous studies, we hypothesized that the rate of a 1-year TLF would be $7 \%$ in the systematic two-stent technique group and $14 \%$ in the provisional stenting group. Accordingly, a total sample size of 600 is needed to detect a power of 0.8 (Type II error $=0.2,=0.05,2$-tailed $)$. Because of the considerable uncertainty, the enrolment is extended to 660 patients ( $10 \%$ increment).

Instead of:

From previous studies, we hypothesized that the rate of a 1-year TLF would be $15 \%$ in the systematic two-stent technique group and $25 \%$ in the provisional stenting group. Accordingly, a total sample size of 600 is needed to detect a power of 0.8 (Type II error $=0.2,=0.05$, 2-tailed). Because of the considerable uncertainty, the enrolment is extended to 660 patients ( $10 \%$ increment).

Open access This is an open access article distributed in accordance with the Creative Commons Attribution Non Commercial (CC BY-NC 4.0) license, which permits others to distribute, remix, adapt, build upon this work non-commercially, and license their derivative works on different terms, provided the original work is properly cited, appropriate credit is given, any changes made indicated, and the use is non-commercial. See: http://creativecommons.org/licenses/by-nc/4.0/.

C A Author(s) (or their employer(s)) 2018. Re-use permitted under CC BY-NC. No commercial re-use. See rights and permissions. Published by BMJ.

BMJ Open 2018;8:e020019corr1. doi:10.1136/bmjopen-2017-020019corr1

Check for updates 